\title{
Excellent Commodity of Capture Fisheries and Preservation of Fish Resources in Pekalongan City
}

\author{
Azis Nur Bambang, Imam Triarso, Abdul Kohar Muzakir \\ Faculty of Fisheries and Marine Science, Diponegoro University, Semarang, Indonesia
}

\begin{abstract}
Pekalongan City is a coastal area on the north coast of Central Java Province, which has a fairly large fishing port, namely Pekalongan Archipelago Fishery Port.. This research objective to determine the exellent commodities of capture fisheries and efforts to preserve capture fisheries resources. Descriptive research methods have been used in this research. The data taken is secondary data from literature studies and related institutions, because the time of the research was still in the Covit 19 pandemic. Analysis of the data used is quantitative descriptive analysis. The research results showed that the dominant fishing gear was Purse seine and Gillnet. Purse seine vessels used are mini purse seine $(<30 \mathrm{GT})$ and pursein $(>30 \mathrm{GT})$. Exellent commodity include Layang (Decapterus sp), Tonngkol (Thunnus tonggol) and Tembang (Sardinella fimbriata). Efforts to preserve fish resources in the City of Pekalongan are done by regulating the number of fishing gear and limiting the number of production and the number of fishing trips. The government policies in the effort to maintain the sustainability of fish resources include: banning the use of trawl and seine net, determination of Fisheries Management Areas (WPP) and limitation on the amount of catches allowed $(J T B)$, as well as establishing fishing lanes.
\end{abstract}

Keywords: Pekalongan City, Exellent commodity, Capture Fisheries.

\section{Introduction}

One of the cities in Central Java which is the center of fishery activities is Pekalongan City. Pekalongan City is located on the north coast of Central Java Province with an area of 45.25 $\mathrm{km} 2$ consisting of 4 (four) districts, namely North Pekalongan, South Pekalongan, East Pekalongan, and West Pekalongan. The city is known for its potential and capture fisheries products and has a type B port, the Pekalongan Archipelago Fishery Port /PPNP [1,2,3]. The large potential and production of marine fisheries has a good influence on the economic development of fisheries in Pekalongan City and surrounding areas. Capture fisheries production or in this case is sea fish, in 2019 as many as 13,490,107 tons showed an increase in production compared to the previous year, which was a number of $12,815.64$ tons. The types of fish caught in the city of Pekalongan are pelagic fish and demersal fish. $[12,13]$

\footnotetext{
*Corresponding author: azis undip2013@yahoo.com
} 
By maximizing activities in the superior fisheries sector, it can increase the success of fisheries development that has been achieved in the previous year. To increase economic growth is to determine the excellent commodities which are the economic driving sector of the city, so that the determination of superior commodities for fisheries is the first step for the region to create economic growth $[18,32]$. In an effort to realize the economic growth of fisheries in this region, the focus of this study aims to determine the leading commodity of fisheries in Pekalongan City and its preservation.

Excellent commodity is researched using quantitative and qualitative analysis based on the number and types of fish caught, as well as the number and types of fishing gear in Pekalongan City.

\section{Research Objective and Location}

This study aims to determine the leading commodities of capture fisheries and efforts to preserve capture fisheries resources in the city of Pekalongan

\subsection{Data Collection.}

The data is taken is secondary data from literature studies and related institutions, because the time of the research was still in the corona virus / Covit 19 pandemic. Data collection includes data on the production of fish caught at sea, the value of fish production, fish production per month and the number of fishermen and the number of fishing fleets. The data was taken from various sources, among others, from the Pekalongan City Fisheries Statistics book, Statistics of Central Java fisheries, the Annual Report of the Archipelago Fisheries Port, Bappeda, Central Java Marine and Fisheries Profiles, and from journals related to the analysis of fisheries exellent commodity.

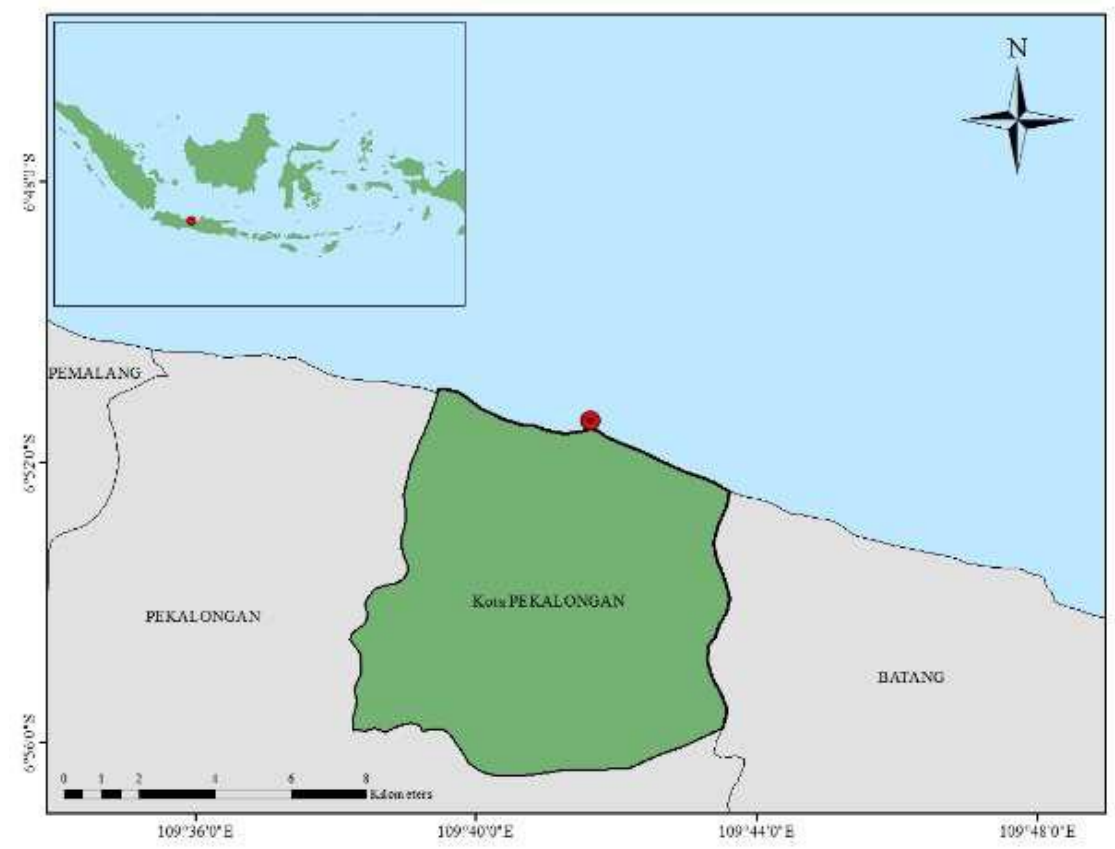

Fig.1. Map of Pekalongan City. PPN Pekalongan 


\subsection{Data analysis}

Data analysis were including data on the production of fish caught at sea, the value of fish production, production per type of fish and the fishing fleet 2015-2018. The analysis of the sustainability of fish resources in this study includes: Efforts by the government to protect fish resources in Pekalongan City and government policies in efforts to maintain the sustainability of marine fishery resources.

\section{Result and Discussion}

Pekalongan City is located in the lowlands of the north coast of Central Java, having an area of 4,525 $\mathrm{km} 2$. This city is a lowland that does not have a steep area with an average height of 1 meter above sea level. Pekalongan City has a coastline of around $6.15 \mathrm{~km}$ which is the basis of capture fisheries activities. Administratively, the area of the city of Pekalongan lies between $109^{\circ} 37^{\prime} 55^{\prime \prime}$ up to $109^{\circ} 42^{\prime} 19^{\prime \prime}$ East and $06^{\circ} 50$ ' 42 "up to $06^{\circ} 55^{\prime} 44^{\prime \prime}$ LS. [4,5]. The Pekalongan city area has a fairly large port (class B), namely the Pekalongan Archipelago Fisheries Port (PPN) in the northern part of the city of Pekalongan. This port faces the Java sea, making it easier to use marine fisheries resources in the Java Sea. The distance between Pekalongan City and the capital of Central Java Province (Semarang) is $101 \mathrm{~km}$ and has a distance of $384 \mathrm{~km}$ from the capital of the Republic of Indonesia (Jakarta)

\subsection{Fish production in Pekalongan City}

The volume of fish landings at the Pekalongan Archipelago Fisheries Port (PPN) in 2018 reached $12,815,639.89 \mathrm{~kg}$ with a production value of $\mathrm{Rp} .199,088,760,603.45$, - Compared to a year ago a decline in production of $0.25 \%$ was accompanied by a decrease in production value of $3.81 \%$. The average fish production landed every day is around 35.11 tons with an average price of $\mathrm{Rp} .15,534.82 / \mathrm{kg}$ or in other words the average price decreased $3.57 \%$ compared to last year. In 2018 is the year of the Weak La Nina condition which causes uneven rainfall in every region of Indonesia. Uneven and not too high rainfall conditions affect the number of ships that go to sea, especially for vessels under 30 GT. Weak La Nina conditions cause little rainfall so that the sun lasts longer to support the availability of plankton at sea and increase salinity. In 2018, many fish landed from the Gill Circle ring. Where the average normal landing between 2 to 4 tons in 2018 the number of landings reached 7 to 9 tons / trip. With more and more ships using freezers, the quality of landed fish is better. Fish that have better quality, will affect the price of fish which is getting higher too. Catching time using a freezing device can be longer at sea, whereas those who use ice when the ice runs out will immediately land the fish $[7,8,9]$

Based on Fig.2, the production and production value of capture fisheries products in Pekalongan city from year to year fluctuates every year. The fluctuating amount of production is presumably due to the influence of the fish season and also the influence of the number of fleets that landed their fish at the Pekalongan Archipelago Fishery Port (PPNP). From Fig. 3 shows that the production per month is quite a lot in the months between July to December 


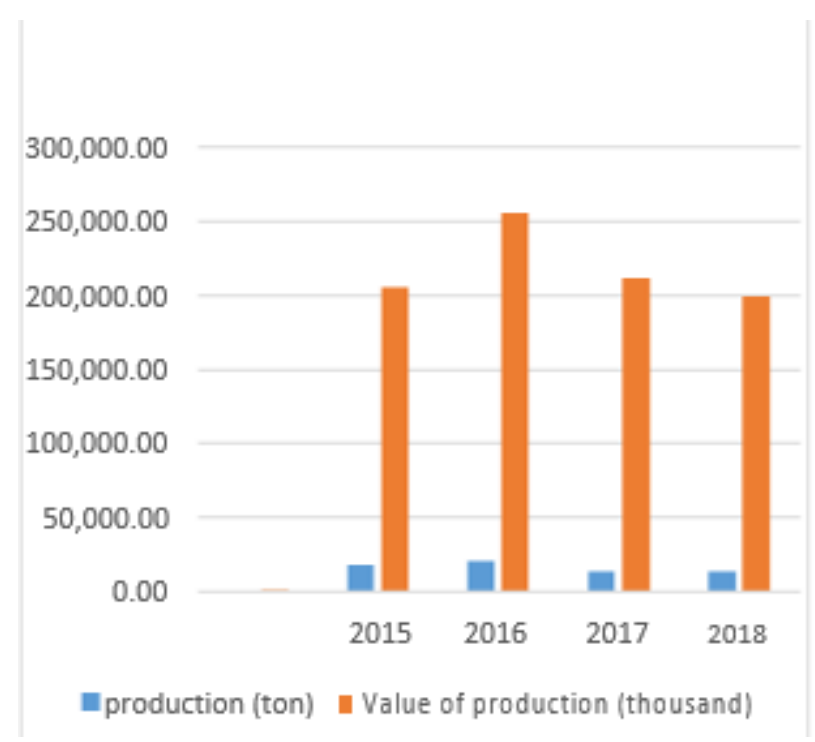

Fig. 2. Production and production value of fish catches (Pekalongan Archipelago Fisheries Port, 2019)

\subsection{Fishing Season}

The fishing season at the Pekalongan Archipelago Fisheries Port ranges from June to October because in those months there is an increase in production or peak season when compared to other months. The transition season is divided into two, namely the initial transition that occurs in March to June and the final transition in October to November. During this transition month fishermen usually start fishing operations (Graph 2). At the moment in the Pekalongan Archipelago Fisheries Port, many ships come from outside the area, especially purse seine ships from East Java. Pekalongan serves as a base for fishing on the north coast of Central Java $[10,11,27]$. 


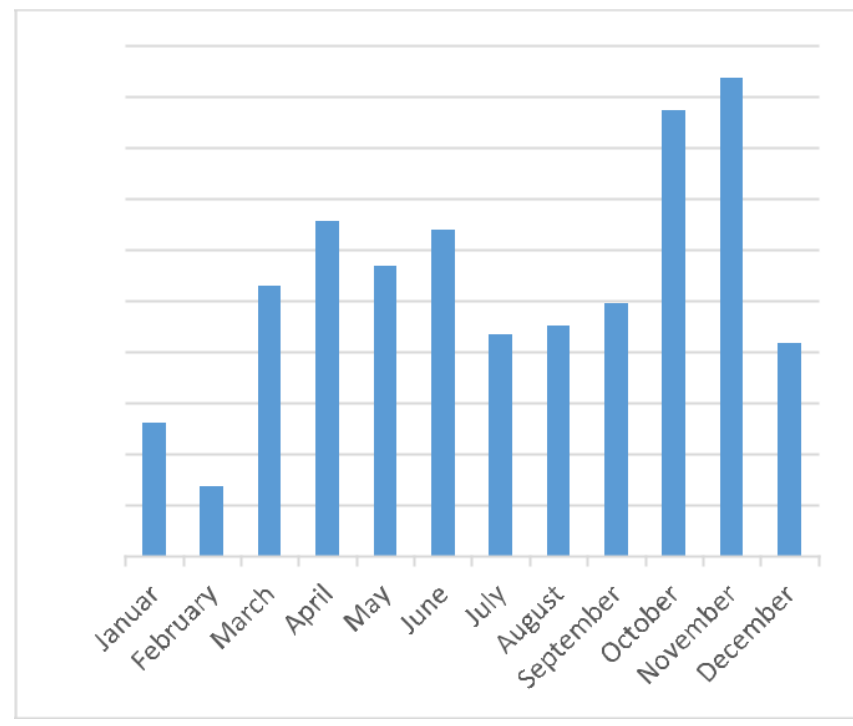

Fig. 3. Production of fish catches (tons) per month (tons) in 2018 (Pekalongan Archipelago Fisheries Port, 2019)

The fish landing season in PPN Pekalongan is divided into two groups. Famine (not fish) season is common in the first (1) and third (3) quarters while in the second (2) and fourth (4) quarters is the peak of fish landing. But in 2018 there seems to be a shift in the fish season.

During 2018 the influence of the Weak La Nina season occurred due to erratic rainfall and the influence of the Cempaka storm which affected the fishing conditions with high wave conditions which forced fishermen not to go to sea. In addition, the change of the west and east monsoons which is longer than usual causes high waves and strong currents that cause the ship to be unable to operate. The existence of Weak La Nina's condition affects the salinity or salt content of the sea and the amount of sunlight received by the sea. Poor salt content and lighting conditions will affect the availability of plankton as fish food. Less fertile areas cause the fish population is also small. Landed fish are dominated by small pelagic fish.

\subsection{Fishing Ground}

Most of the purse seine fishing areas in the Nusantara Pekalongan Fishery Port are WPP 711 and WPP 713 or precisely in the Masalembo and Matasiri areas (Makassar Strait). It is also in Lumu-lumu and Bawean waters and the South China Sea. The fishing area which is far away makes the trip range between 40-136 days. Likewise, supplies must be prepared for each sea-going distance taken from the fishing base to the fishing ground as far as $25-40$ nautical miles with a travel time of approximately 5-6 hours. The determination of the fishing area is determined by the fishing master using the experience he has, taking into account the current, temperature, wind and wave conditions. Determination of the capture area is usually based on the area that has been tagged on the GPS aids found on the ship.

In 2018 the fishing vessels were mostly in WPP 712 with $97.07 \%$, WPP 713 as many as $2.52 \%$, WPP 572 as many as $0.32 \%$ and WPP 573 as many as $0.09 \%$ of the total number of ships operating as many as 5,596 units. Vessels operating on WPP 713, 572, 573 days at sea range from 50 days to 90 days and are dominated by ships measuring $>30$ GT with Purse Seine fishing gear, while ships operating on WPP 712 operating days range from 3 days to / d 15 days and carried out by ships measuring $<30$ GT dominated by ships Purse Seine and Bottom Gill Net. 


\subsection{Fishing Fleet}

Fishing fleet is one of the main supporting factors in fishing activities at sea and affects the catch. The size of the boat used by fishermen determines the size of the catch because it is related to the length of the fishing trip and the carrying capacity of the boat. The size of the boat used by fishermen determines the size of the catch because it is related to the length of the fishing trip and the carrying capacity of the boat.

Table 1. Number of fishing fleet.

\begin{tabular}{lcccccc}
\hline Tahun & $<\mathbf{1 0 ~ G T}$ & $\mathbf{1 0 - 3 0}$ GT & 30-50GT & 50-100GT & 100-200 GT & Total \\
\hline 2015 & 82 & 116 & 42 & 125 & 69 & 434 \\
2016 & 39 & 126 & 8 & 98 & 31 & 302 \\
2017 & 214 & 112 & 3 & 71 & 10 & 410 \\
2018 & 69 & 74 & 42 & 75 & 41 & 301 \\
\hline
\end{tabular}

Source : Fisheries Statistic Pekalongan City, 2019

The fishing fleet at Pekalongan PPN is dominated by large purse seine vessels $(>30 \mathrm{GT})$ and mini purse seine $(<30 \mathrm{GT})$. The number of crew members who assist arrest operations is 20-40 people per trip. Ship engine power between 250-350 pk for large purse seine. As for the storage of captured fish, it uses the Refrigrated Sea Water (RSW) system. So that the catch is stored frozen. The arrest also used assistive devices in the form of lights and FADs which were not permanent.

\subsection{Fishing gear}

The types of fishing gear used by fishermen in Pekalongan City are varied, such as Purse seine, Payang, Cantrang, Arad, Fishing Line, Trammel net, Gill net, and others. Catches that can depend on the type of fishing gear used. The following number of fishing gear in the city of Pekalongan are as follows [20,21,222,27]:

Table 2. Number of fishing gears in Pekalongan City

\begin{tabular}{ccccccc}
\hline Years & $\begin{array}{c}\text { Purse Seine } \\
\text { >30 GT }\end{array}$ & $\begin{array}{l}\text { Purse } \\
<30 \text { GT }\end{array}$ & Set Gill Net & $\begin{array}{l}\text { Encirling } \\
\text { Gill } \\
\text { Net }\end{array}$ & $\begin{array}{l}\text { Danish } \\
\text { Seine }\end{array}$ & Trap \\
\hline 2015 & 198 & 146 & 25 & 0 & 0 & 0 \\
2016 & 133 & 111 & 47 & 0 & 0 & 0 \\
2017 & 84 & 91 & 48 & 23 & 56 & 31 \\
2018 & 74 & 42 & 48 & 25 & 42 & 66 \\
\hline
\end{tabular}

Source : Fisheries Statistic Pekalongan City, 2019

The most widely available fishing gear at the Pekalongan Archipelago Fishery Port is purse seine. Purse seine fishing gear is a fishing gear that produces the largest production of other fishing gear at the Pekalongan Archipelago Fisheries Port. The catch of purse seine fishing gear is dominated by small pelagic fish. The number of purse seine fishing gear has decreased due to the decrease in the number of fishermen who operate these fishing gear due to changing their livelihoods or moving residence. The number of gillnet fishing gear has increased every year. The gill nets found in Pekalongan consist of gill nets on the surface and drift gills. Gillnet is designed to catch pelagic fish, with the main catch of Gillnet being tuna (Thunnuss cob) and mackerel (Scomberomorus commersoni) [22]. 


\subsection{Type of Fish Catches}

Of the types of fish landed $95.07 \%$ were pelagic fish and the remaining $4.93 \%$ were demersal fish. Of the total pelagic fish, Lemuru Jawa, Tembang Fish, Fly Fish and Mackerel and large pelagic fish such as Setuhuk, Tuna and the like. Demersal fish species commonly caught are Red Snapper, Shark, Side Fish and there are also some large pelagic fish such as White Setuhuk, Sailing Fish and Gray Cobs. Pelagic fish are generally caught with the Trawl Ring fishing gear, while most of the large pelagic fish are caught with the Gill Circle Circle fishing gear. Demersal fish species are generally caught by Fixed Gill Nets [23,27].

\subsection{Fisherman}

Most of the coastal communities in the city of Pekalongan mainly work as fishermen and rarely do fishermen have side jobs. Fishermen who carry out activities in Pekalongan PPN apart from Pekalongan City, there are also fishermen from Rembang, Demak, Pemalang and Tegal and from Tuban (East Java). Generally they use the Mini Purse Seine ship which is operated during the dark moon and the west wind season. This has a pretty good impact on the communities around Pekalongan VAT in particular and Pekalongan City in general, especially in the economic and employment fields $[21,25,26]$.

The number of fishermen in the city of Pekalongan is presented in Graph 3. Based on Fig. 3 , it shows that the number of fishermen is decreasing from year to year, this is allegedly due to the prohibition of fishing using fishing equipment that is not environmentally friendly, such as beam trawl and denish saine [20,21,24].

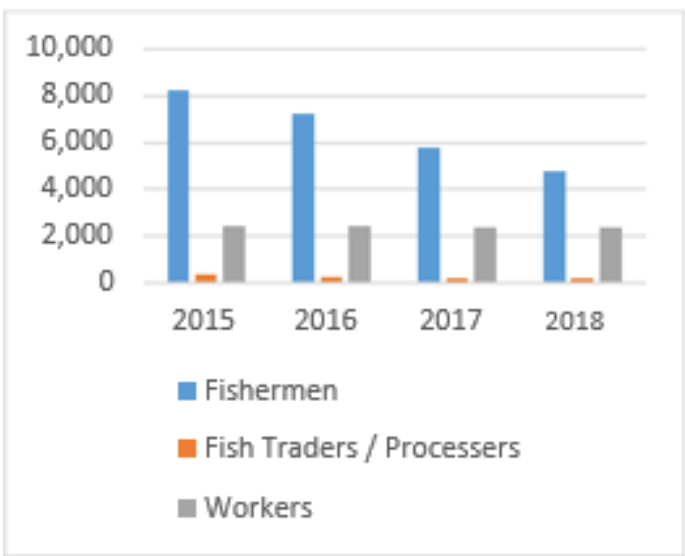

Fig. 3. Total Number of Fishermen in Pekalongan City, 2015-2018 ( Fisheries Statistic Pekalongan City, 2019)

\section{Excelent Commodity}

Excellent commodities that can be a driving force for the development of an area include: Excellent commodities capable of absorbing labor; can last for a certain period of time; must get various forms of support; and oriented towards the preservation of resources and the environment $[18,19]$. When viewed from the point of view of the type of fishing gear that is the most numerous and most productive in the City of Pekalongan is the purse seine fishing gear, both large pusrsein and mini pursein and Gillnet [21,27]. 
Table 3. Fish production in Pekalongan city 2015-2019

\begin{tabular}{llrrrrr}
\hline No & Type of Fish & 2015 & 2016 & 2017 & 2018 & 2019 \\
\hline 1 & Bawal hitam & 204,1 & 321,4 & 152 & 84,5 & 90,60 \\
2 & Cumi - cumi & 180,7 & 124,9 & 175,7 & 166,6 & 174,30 \\
3 & Kembung & 1399,1 & 1465,1 & 955 & 1002,9 & $1.100,70$ \\
4 & Layang & 8293,2 & 7487,6 & 3430,5 & 4287,1 & $4.897,80$ \\
5 & Layur/Jogor & 59,7 & 65,8 & 68,7 & 65,3 & 76,30 \\
6 & Selar & 2720,7 & 3272,8 & 2360,3 & 2306,2 & $2.400,00$ \\
7 & Tembang/Jui & 1167,7 & 2209,4 & 1240,2 & 936,2 & 973,20 \\
8 & Tenggiri & 99,5 & 107,9 & 130,1 & 70,9 & 82,30 \\
9 & Cucut & 64,6 & 48,3 & 6 & 35,5 & 56,70 \\
10 & Petek / Peperek & 28,4 & 23,6 & 67,9 & 50,7 & 64,20 \\
11 & Manyung & 62 & 39,4 & 49,7 & 126,5 & 137,80 \\
12 & Pari Kikir & 2,6 & 0,1 & 0,5 & 7,5 & 6,00 \\
13 & Tongkol & 2021,8 & 2473,3 & 2382,5 & 2649,7 & $2.703,40$ \\
\hline
\end{tabular}

In Pekalongan PPN is dominated by purse seine $>30$ GT fishing gear with 50-90 days fishing time and operating in WPP 711 and WPP 713, so fishermen use freezers to store fish in the hold. Mini purse seine $<30$ GT fishing gear catches for 3-15 days in WPP 712. Purse seine fishing gear has the highest catch followed by mini purse seine and gill net.

When viewed from the type and amount of fish caught in the City of Pekalongan (Table 3), it shows that the Layang fish (Decapterus sp), Tuna fish, Selarides (Selaroides sp), and Mackerel fish (Rastrelliger sp) and Tembang / Jui fish (Sardinella fimbriata ) has a high amount of production.. According to Naya et al 2017 the main commodities of capture fisheries in Central Java Province include floating fish (Decapterus sp), mackerel (Rastrelliger sp), selarides (Selaroides sp) and tembang fish (Sardinella fimbriata)

When viewed in terms of catch commodity prices, it shows that the Layang fish (Decapterus sp), Tuna fish, Selarides (Selaroides sp), and Mackerel (Rastrelliger sp) and Tembang / Jui (Sardinella fimbriata) fish respectively are 18.000-35.00, 42.000-80.000, $15.000-25.000,45.000-55.000$ and 10.000-22.000 IDR/kg.

\section{Preservation of Fish Resources}

Pekalongan City is located in the north coast of Java, so that the fish resources in Pekalongan City are quite abundant and efforts are needed to optimize these fish resources. One of the leading sectors in the City of Pekalongan is the fisheries sector. Sustainability efforts in increasing leading fishery commodity in Pekalongan City are [6,7]:

1. Setting the number of fishing gear

2. Limiting the amount of production per season or per year in order to preserve fish resources.

3. Setting the number of fishing trips

4. Providing counseling to fishermen regarding handling fish on the boat so that the catches obtained when landed are fresh so that the quality of the fish does not go down and the prices obtained are high.

The government policies in an effort to maintain the sustainability of existing fish resources include $[10,16,17,28,30,31]$ :

1. Prohibition of the use of trawl and trawl (seine net) fishing gear.

2. Decree of the Minister of Maritime Affairs and Fisheries No. 06 of 2010 concerning Fishing Equipment in WPPNRI. 
3. Determination of potential fish resources and the amount of catch allowed (JTB).

4. Minister of Maritime Affairs and Fisheries Regulation No. 71 of 2016 concerning fishing lanes and the placement of fishing gear.

According to Wijayanto et al (2019a,2019b), in controlling denish seine, through fishing permits, the government has limited the tonnage and number of ships but does not regulate maximum engine power. To manage of capture fisheries from the aspect of fish resource sustainability requires policies such as: (1) conservation and rehabilitation of mangrove forests, (2) regulation and distribution of the number of fishing gear, (3) post-harvest processing, (4) revitalization and modernization of large fleets operating in offshore areas(5) the prohibition and reduction of small fleets that are inefficient and not environmentally friendly, (6) the development of downstream industries in terms of fish processing, (7) management and capacity building of fisheries and marine institutions, (8) diversification and efforts to provide alternative livelihoods, ( 9) stock enrichment program, (10) intensifying sea patrols to prevent illegal fishing [28].

According to Dian Ayunita et al, 2017, most of the purse seine catches in Pekalongan city are small pelagic fish species, such as floating fish (Decapterus sp), layur (Trichiurus lepturus), banyar fish (Rastrelliger kanagurta), lemuru fish (Sardinella lemuru), squid (Loligo $\mathrm{sp}$ ), bentong fish (Selar crumenophthalmus), tuna (Thunnus sp) and others [17]. According to Rofiqoh et al (2017) the results of the assessment of the level of environmental friendliness of gillnet fishing gear in terms of the weight and the amount of environmentally unfriendly. However, when viewed from the level of utilization of by-products are environmentally friendly[23].

\section{Conclusion}

Exellent Commodity of capture fisheries in terms of fishing gear shows that the dominant fishing gear is Purse seine and gillnet. Purse seine vessels used are mini purse seine $(<30$ GT $)$ and pursein ( $>$ 30GT. Exellent commodity in terms of types of catch fish include Layang (Decapterus sp), Tongkol fish, Selar fish (Selaroides sp), and mackerel fish (Rastrelliger sp) and Tembang / Jui fish (Sardinella fimbriata).

Efforts to preserve fish resources in the City of Pekalongan are done by regulating the number of fishing gear and limiting the number of production and the number of fishing trips. The government policies in the effort to maintain the sustainability of fish resources include: banning the use of trawl and seine net, determination of Fisheries Management Areas (WPP) and limitation on the amount of catches allowed (JTB), as well as establishing fishing lanes

\section{Acknowledgements}

The team of researcher would like to thank FPIK-Diponegoro University for funding our research. Also to Ayu Fitriyani, S.Pi who has assisted in data collection and processing of our research data, we are also grateful to the Pekalongan City Marine and Fisheries Service and Pekalongan City PPNP and the Central Java Marine Fisheries Service for providing support for our research. 


\section{References}

1. Badan Pusat Statistik (BPS) Kota Pekalongan (Statistics of Pekalongan Municipality). Fisheries Statistics 2015-2018. BPS Pekalongan. ISSN / ISBN : 978-602-6415-30-1

2. Badan Pusat Statistik (BPS) Kota Pekalongan (Statistics of Pekalongan Municipality). City of Pekalongan in Figures. BPS City of Pekalongan (2019)

3. Badan Pusat Statistik (BPS) Kota Pekalongan, (Statistics of Pekalongan Municipality). North Pekalongan District in Figuress. BPS. Pekalongan. ISBN : 978-602-6415-36-3. (2019)

4. Badan Pusat Statistik Kota Pekalongan (Statistics of Pekalongan Municipality). Statistics of Pekalongan city [in Indonesian]. (2018)

5. Badan Pusat Statistik. (Statistics of Pekalongan Municipality. Gross Regional Domestic Production by Business Field of Pekalongan City. BPS City of Pekalongan. (2016)

6. Bambang AN and Y Bambang, Environmental friendly study of fishing tools at TPI Ujungbatu Jepara District. Proceeding of National Seminar, Postgraduate Research Results UNDIP Semarang.. ISBN: 978-602-60921.(2016)

7. Decree of the Minister of Maritime Affairs and Fisheries No. 47 of 2016 concerning Estimation of Potential, Number of Catches Allowed, Level of Utilization of Fish Resources in the Fisheries Management Region of the Republic of Indonesia

8. Department Maritime Affairs and Fisheries of Central Java Province. 2016. Annual Data on Capture Fisheries in Central Java Province 2016. Semarang

9. Department of Marine Affairs and Fisheries of Pekalongan City. 2017. Pekalongan City Marine and Fisheries Potential Profile.(2017)

10. Dewi, 2016 Composition of Danish seine catches and biological aspects of Saurida tumbillat Bajomulyo coastal fishing port, Juwana. Diponegoro Journal of Marine Resources. 5(2): 17-26. [in Indonesian].(2016)

11. Dian Ayunita N.N. Dewi, B.A. Wibowo dan Iqbal Ali Husni, 2017. Purse Seiners Fishing Sustainability at Pekalongan : An Overview of Technical Efficiency Aspect. Akuatik Jurnal of water resources. XI (2): 7-14 (2017)

12. Directorate General of Capture Fisheries, Ministry of Maritime Affairs and Fisheries 2019. Annual Report 2018. Pekalongan Archipelago Fishery Port (PPN) Pekalongan.

13. DKP Pekalongan city. The Fisheries Data of Pekalongan city (Unpublish). DKP Kota Pekalongan [in Indonesian] (2018)

14. DKP Provinsi Jawa Tengah, 2017. [Statistic of fisheries capture of Central Java Province,2016]. DKP of Central Java Province, 201 pp. [in Indonesian]( 2017)

15. Minister of Marine Affairs and Fisheries Regulation No. 02/2011 concerning Fishing Routes

16. Minister of Maritime Affairs and Fisheries Regulation No. 2 of 2015 concerning Prohibition.The Use of Trawl and Seine Nets [in Indonesian]

17. Minister of MMAF Decree No. 2 of 2015 [Prohibition of using trawls and seine nets in Fisheries Management Areas of the Republic of Indonesia]. Ministery of Maritime Affair and Fisheries, 10 pp. [in Indonesian] 
18. Naya B.A.D, Dian Wijayanto, Sardiyatmo. Analisis Komoditas Unggulan Perikanan Tangkap di Provinsi Jawa Tengah . Basic Commoditties Analysis of Capture Fisheries in Central Java Province. Journal of Fisheries Resources Utilization Management and Technology 6(3) :37-46 (2017). Online di: http://www.ejournalsl.undip.ac.id/index.php/jfrumt

19. Nova Rodhiyana Mustofa, Abdul Kohar Mudzakir, Faik Kurohman. Excellent Commodity-Based Development of Capture Fisheries in Pekalongan Regency. Journal of Fisheries Resources Utilization Management and Technology. VII (2):68-77 (2018)

20. Pekalongan Archipelago Fishery Port. Number of Fishing Vessels by Type of Fishing Gear at Pekalongan Archipelago Fishing Port. PPN Pekalongan (2016)

21. Pekalongan City Regional Development and Research Planning Agency (BAPPEDA) and Pekalongan City Central Statistics Agency (BPS). Pekalongan City in Numbers. BAPPEDA and BPS Kota Pekalongan (2016)

22. Rafdi A. M, Sardiyatmo, and F. Kurohman. Analyze The Effect Of Time Setting And The Withdrawal Of Purse Line On The Catch Result Of Mini Purse Seine Place On Fishery Port Of Nusantara (PPN) Pekalongan Journal of Fisheries Resources Utilization Management and Technology. VI (4):11-19 (2017). https://ejournal3.undip.ac.id/ index.php/ jfrumt/issue/archive

23. Rofiqo I.S., Zahidah, Kurniawati N and Dewanti L.P. Level of environmentally fishing with gillnet gear againts total catch mackarel tuna (ethynnuss $\mathrm{sp}$ ) in pekalongan sea water. Jurnal Perikanan dan Kelautan. X (1): 64-69 (2019)

24. Statistic of Pekalongan Archipelagic Fishing Port,2019. Pelabuhan Perikanan Nusantara Pekalongan. Februariy 2019. Pekalongan

25. Statistics of Central Java Province, 2016. Gross Regional Domestic Production According to Central Java Business Field 2016. BPS Central Java Province. Semarang

26. Statistics of Central Java Province, 2018. Marine Fishery Production which is sold at TPI Central Java Province. BPS of Central Java Province, Semarang

27. Statistik PPN Pekalongan (Statistic of Pekalongan Archipelagic Fishing Port), 2019. The Annual Statistical Report of Pekalongan Archipelagic Fishing Port.

28. Suharno and T.Widayati , 2017. Policy on the management of small-scale fishermen's capture fisheries business on the North coast of Central Java. Proceedings of a multidisciplinary National Seminar \& call for papers Unisbank.ISBN: 978-979-3649-81-8

29. Utomo M.T.S., Djasmani S.S., Saksono H., Suadi S. Business analysis of purse seine in Juwana Subdistrict of Pati Regency. J. Fish. Sci XV(2): 91-100 (2013) [in Indonesian]

30. Wijayanto D., Bambang A. N., Kurohman F. The impact of 'cantrang' (Danish seine) fisheries on gill net fisheries in Tegal coastal area, Indonesia. AACL

Bioflux12(4):1005-1014 (2019b)

31. Wijayanto D., Sardiyatmo, Setyanto I., Kurohman F. A Bioeconomic Analysis of the Impact of 'Cantrang' (Danish seine) Toward Gill Net in Pati Regency, Indonesia.AACL Bioflux 12(1):25-33 (2019).

32. Yusrin F.L., Mudzakir A.K.dan Sardiyatmo. 2017. Analysis of Leading commodities of fishing in Pemalang district. Journal of Fisheries Resources Utilization Management and Technology. VI (4):276-283. https://ejournal-s1.undip.ac.id/index.php /jfrumt 